\title{
Further evidence for the development of photic-zone euxinic conditions during Mesozoic oceanic anoxic events
}

\author{
RICHARD D. PANCOST ${ }^{1}$, NEAL CRAWFORD ${ }^{1}$, SIMON MAGNESS $^{1}$, ANDY TURNER ${ }^{1}$, \\ HUGH C. JENKYNS ${ }^{2}$ \& JAMES R. MAXWELL ${ }^{1}$ \\ ${ }^{1}$ Organic Geochemistry Unit, Biogeochemistry Research Centre, School of Chemistry, University of Bristol, Cantock's \\ Close, Bristol BS8 1TS, UK (e-mail: R.D.Pancost@bristol.ac.uk) \\ ${ }^{2}$ Department of Earth Sciences, University of Oxford, Parks Road, Oxford OX1 3PR, UK
}

\begin{abstract}
Periods in Earth history characterized by extensive organic carbon deposition, so-called oceanic anoxic events (OAEs), are the subject of considerable scrutiny. Insight into the extent of anoxic conditions in the water column has been provided by the reported occurrence of derivatives of isorenieratene, a carotenoid found only in green sulphur bacteria and thus indicative of photic-zone euxinia (i.e. a water column containing free $\mathrm{H}_{2} \mathrm{~S}$ ), in North Atlantic deep-sea sediments deposited during the Cenomanian-Turonian boundary OAE2 (Bonarelli Event). In this study, we have used the distributions of chlorophyll and bacteriochlorophyll degradation products, maleimides (1- $H$-pyrrole-2,5-diones) and high molecular weight porphyrins, to examine further the Cenomanian-Turonian boundary OAE2 as well as other OAEs of the early Toarcian (Posidonienschiefer Event) and early Aptian (Selli Event). In particular, methyl isobutyl (Me, $i$-Bu) maleimide, on structural grounds, appears to be diagnostic of green sulphur bacteria. This compound occurs in five of seven examined marls that record the early Toarcian OAE (Marche-Umbria, Italy), further expanding the geographical range of Toarcian sediments where evidence for photic-zone euxinic conditions has been found. $\mathrm{Me}, i$-Bu maleimide occurs in three of six black shales spanning the Livello Selli (Marche-Umbria, Italy), the type locality for the Aptian OAE1a, providing the first evidence for photic-zone euxinic conditions during this event. With respect to the Cenomanian-Turonian OAE, maleimide evidence for photic-zone euxinic conditions was found in all the North Atlantic sites investigated, including those characterized by relatively organic-lean sediments, several Tethyan sites and one site off western Australia. These data indicate that euxinic conditions were common in the water column during Mesozoic oceanic anoxic events.
\end{abstract}

Keywords: ${ }^{13} \mathrm{C} /{ }^{12} \mathrm{C}$, Jurassic, Cretaceous, maleimides, oceanic anoxic events.

One of the most intriguing aspects of Mesozoic climate is the episodic occurrence of so-called oceanic anoxic events (OAEs). Originally, the term OAE was used to describe the phenomenon characterized by seemingly global distribution of laminated organic-carbon-rich $(>1 \%)$ sediments in pelagic sequences of Aptian-Albian and Cenomanian-Turonian boundary age (Schlanger \& Jenkyns 1976). Since then, other episodes of widespread black-shale deposition in marine environments have been identified, and six OAEs have been proposed for the midCretaceous (Arthur et al. 1990) and one for the Jurassic (Jenkyns 1988). These events are often associated with periods of dramatic climatic change and biotic turnover, and each apparently represents the sequestration of vast quantities of organic carbon into the geosphere (e.g. Jenkyns 1999, 2003). Consequently, black shales deposited during OAEs are among the most organic-rich marine sediments and are important petroleum source rocks. Significant positive excursions in ${ }^{13} \mathrm{C} /{ }^{12} \mathrm{C}$ ratios of marine carbonates (up to 2.5\%) and organic matter (up to 6\%o) in early Aptian time (OAE1a) and at the Cenomanian-Turonian boundary (OAE2) provide additional evidence for the enhanced removal of ${ }^{13} \mathrm{C}$-depleted organic carbon from the ocean-atmosphere reservoir (Arthur et al. 1988; Weissert et al. 1998).

Interest in OAEs has stimulated diverse investigations using sedimentological, palaeontological and geochemical approaches. However, the underlying causes and unifying characteristics of OAEs remain poorly understood. Black shales deposited during OAEs share similarities such as high organic carbon contents, lamination and impoverished benthic fauna, indicating that these sediments were deposited under oxygen-deficient bottom-water conditions (Summerhayes 1987; Bralower et al. 1994). Models to explain these observations typically invoke either enhanced organic matter preservation and/or enhanced primary productivity (Demaison \& Moore 1980). Preservation models propose that either restricted circulation or elevated temperatures at the sites of bottom-water formation resulted in a decreased oxygen flux and decreased organic matter remineralization (e.g. Ryan \& Cita 1977; Brass et al. 1982; Barron 1983; de Graciansky et al. 1984). In contrast, productivity-driven models propose that enhanced primary productivity during OAEs resulted in increased burial of organic matter (e.g. Pedersen \& Calvert 1990; Erbacher et al. 1996; Sinton \& Duncan 1997).

Given the complex changes in ocean circulation, primary productivity, redox conditions and biological populations associated with OAEs, molecular biogeochemical approaches, which can provide insight into photoautotroph and bacterial communities, are useful complements to classical inorganic and palaeontological techniques. Of particular interest in the study of OAEs are biomarkers derived from green sulphur bacteria that are diagnostic for photic-zone euxinic conditions (e.g. Summons \& Powell 1986). Such biomarkers have been found in organic-rich sediments throughout the Phanerozoic (e.g. Koopmans et al. 1996), including those deposited during Mesozoic OAEs (Sinninghe Damsté \& Köster 1998; Schouten et al. 2000). Identification of biomarkers for green sulphur bacteria has proved to be particularly useful in reconstructing oceanographic conditions during OAEs by helping to constrain the extent of 
water-column redox variations. Here, we expand on such analyses using maleimides (1- $H$-pyrrole-2,5-diones), degradation products of tetrapyrrole pigments that can be diagnostic of specific photoautrophic organisms, including green sulphur bacteria.

\section{The origin of maleimides}

Maleimides in geological samples derive from the degradation of chlorophylls, the predominant light-harvesting compounds in photoautotrophic organisms. The most abundant chlorophyll, Chl $a$, is present in all photosynthetic eukaryotes and cyanobacteria, whereas the anoxygenic prokaryotes typically contain bacteriochlorophyll (Bchl) $a$ or, less commonly, Bchl $b$ (e.g. Keely \& Maxwell 1993, and references therein). Bchls $c, d$ and $e$ (Fig. 1, I) in marine settings are largely restricted to the Chlorobiaceae, the photosynthetic green sulphur bacteria. The Chlorobiaceae are of particular interest because they require both light and free hydrogen sulphide (van Gemerden \& Mas 1995), and diagenetic products of their lipids are diagnostic for the specific conditions of photic-zone euxinia (e.g. Summons \& Powell 1986). Specific concentrations of hydrogen sulphide are difficult to ascertain; green sulphur bacteria can apparently live at relatively low hydrogen sulphide concentrations $(<1 \mu \mathrm{M})$ as long as $\mathrm{O}_{2}$ is absent and light is available (e.g. Repeta et al. 1989).

Although most chlorophyll is degraded to lower molecular weight colourless products (Brown et al. 1990), a small proportion can undergo transformation to yield sedimentary porphyrins, which have a fully aromatic tetrapyrrole ring structure and exist as mainly nickel or vanadyl complexes. Such porphyrins can serve as useful tracers for ancient photoautotropic communities, with certain high-molecular-weight porphyrins apparently deriving from Bchls $c, d$ and $e$. However, difficulties associated with identifying specific components in complex mixtures (e.g. Turner 1998) complicate the use of porphyrins as biomarkers for green sulphur bacteria and, in this paper, porphyrins are used to complement interpretations based on maleimides. Maleimides (1$H$-pyrrole-2,5-diones) can be obtained from treatment of chlorins or porphyrins with an oxidizing agent, by photoxidation or autoxidation in ancient depositional settings or oxidation during sample storage (P. Adam, pers. comm.). Analyses of geological materials utilizing various porphyrin oxidation schemes (Hodgson et al. 1971; Quirke et al. 1980) or examination of solvent-extractable (free) maleimides (Grice et al. 1996) resulted in the identification of a suite of maleimides, including $\mathrm{H}, \mathrm{H}$,
Me,Et (IIa), Me,Me (IIb), Et,Et (III), Me, i-Bu (IIc), Me,sec-Bu (IId), Me, $n$ - $\mathrm{Bu}$ (IIe), Me,H (IIf), Me, $i-\mathrm{Pr}$ (IIg) and $\mathrm{Me}, n$-Pr (IIh) maleimides (where Me is methyl; Et, ethyl; Pr, propyl; $i$-Pr, isopropyl; $\mathrm{Bu}$, butyl; sec-Bu, secondary butyl; $i$-Bu, isobutyl). On structural grounds, all of these could be attributed to one or more chlorophylls; for example, Me,Et maleimide, which is particularly abundant in most sediments, probably derives from $\mathrm{Chl} a$. Of significance are the $\mathrm{Me}, n-\mathrm{Pr}$ and $\mathrm{Me}, i$-Bu components, which, on structural grounds, appear to derive from $\mathrm{Bchl} c, d$ or $e$. At present, there is no known precursor for $\mathrm{Me}, i$-Bu maleimide other than $\mathrm{Bchl} c, d$ or $e$, all of which contain an $i$-Bu side chain at C-8. There is, however, an alternative source for $\mathrm{Me}, n-\mathrm{Pr}$ maleimide: hydrolysis of the $\mathrm{C}-17$ ester in $\mathrm{Chl} a$, followed by reduction of the resulting $\mathrm{C}_{3}$ acid substituent (Verne-Mismer et al. 1986).

Hence, the relative abundances of $\mathrm{Me}, i$-Bu maleimides can be used as a proxy for the presence of Chlorobiaceae in ancient water columns and the specific condition of photic-zone euxinia. In addition, because maleimides can be unambiguously linked to precursor chlorophylls or bacteriochlorophylls, their carbonisotopic compositions could be useful in reconstructing changes in the carbon cycle that are often associated with OAEs (e.g. Arthur et al. 1988). Here, we report analyses of maleimide distributions and carbon-isotopic compositions in organic-rich sediments associated with the three most significant Mesozoic oceanic anoxic events: the early Toarcian (Posidonienschiefer Event), the early Aptian (Selli Event; OAE1a), and at the Cenomanian-Turonian boundary (Bonarelli Event; OAE2). Specifically, we illustrate the utility of maleimides in identifying photic-zone euxinia in ancient restricted basins and how this complements other organic geochemical tools (e.g. abundances of isorenieratene degradation products).

\section{Methods}

\section{Sample extraction and fractionation}

Powdered sediments $(30-250 \mathrm{~g})$ were extracted $(\times 3$ or $\times 4)$ by sonication (20 min) in $\mathrm{CH}_{2} \mathrm{Cl}_{2}-\mathrm{MeOH}(9: 1, \mathrm{v} / \mathrm{v})$. Extracts were fractionated according to methods published previously (Grice et al. 1997). In short, they were separated by flash chromatography into four fractions, containing: aliphatic hydrocarbons (F1); Ni porphyrins and aromatic hydrocarbons (F2); vanadyl (VO) porphyrins (F3); maleimides (F4). Another stage of flash-column chromatography was used to separate F2 into discrete aromatic and $\mathrm{Ni}$ porphyrin fractions and to obtain from $\mathrm{F} 4$ a crude maleimide fraction. The latter was purified further by thin layer
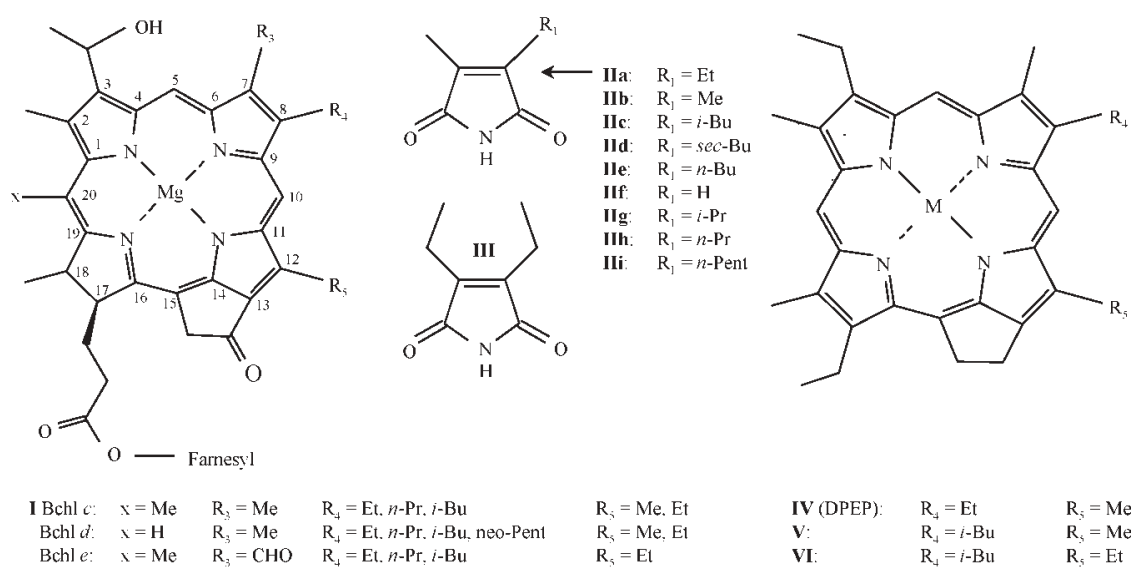

$\mathrm{R}_{4}=\mathrm{Et}, n-\mathrm{Pr}, i-\mathrm{Bu}$

$\mathrm{R}_{+}=\mathrm{Et}_{.} n-\mathrm{Pr}, i-\mathrm{Bu}$
$\mathrm{R}_{\mathrm{s}}=\mathrm{Me} . \mathrm{Et}$

$\mathrm{R}_{5}=\mathrm{Me} . \mathrm{E}$

$\mathrm{R}_{5}=\mathrm{El}$

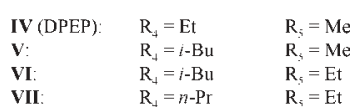

Fig. 1. Structures of bacteriochlorophylls $c$, $d$, and $e(\mathbf{I})$; matelimides (II); including $\mathrm{Me}, i$-Bu maleimide (IIc) diagnostic for green sulphur bacteria; and porphyrins (IVVII) of which V-VII are diagnostic for green sulphur bacteria. 
chromatography (TLC; modified from Grice et al. (1997) and described by Pancost et al. (2002)).

\section{Demetallation and oxidation of porphyrins}

Demetallation of metalloporphyrins was performed using the method of Chicarelli (1985) and confirmed by UV-visible spectrophotometry. Resultant free base porphyrins (typically $0.5-1 \mathrm{mg}$ ) were oxidized to maleimides by UV light oxidation. The mixture, in $40 \mathrm{ml}$ acetone in a round-bottomed flask carrying a condenser, was irradiated until bleached (typically $12-24 \mathrm{~h}$ depending on the amount of starting material) using a Gallenkamp UV lamp (365 nm) with a $125 \mathrm{~W}$ bulb. Solvent was removed by rotary evaporation and the maleimides were purified by TLC as outlined above. Porphyrin fractions obtained by flash-column chromatography were identified as $\mathrm{Ni}$, VO or free base species by UV-visible spectrophotometry using a Unicam UV2 spectrophotometer according to the methods of Chicarelli (1985). Liquid chromatography-atmospheric pressure-mass spectrometry was performed using a method similar to that of Rosell-Melé et al. (1996) and described by Pancost et al. (2002).

\section{Gas chromatography (GC) and gas chromatography-mass spectrometry $(G C-M S)$}

GC and GC-MS methods have been described previously (Pancost $e t$ al. 2002) and were conducted on both derivatized and underivatized maleimides. Underivatized maleimides were analysed using a CPWAX 52 $\mathrm{CB}$ column (Chrompack; $25 \mathrm{~m} \times 0.32 \mathrm{~mm}$ i.d., $0.2 \mu \mathrm{m}$ film) with the following temperature programme: $40^{\circ} \mathrm{C}$ to $100^{\circ} \mathrm{C} @ 10^{\circ} \mathrm{C} \mathrm{min}{ }^{-1}$ then to $250^{\circ} \mathrm{C} @ 4^{\circ} \mathrm{C} \min ^{-1}$ (isothermal for $25 \mathrm{~min}$ ). Derivatized maleimides were analysed using a CPSIL 5 column (Chrompack; $25 \mathrm{~m} \times 0.32 \mathrm{~mm}$ i.d., $0.12 \mu \mathrm{m}$ film) with the following temperature programme: $40^{\circ} \mathrm{C}$ (2 min) to $80^{\circ} \mathrm{C} @ 10^{\circ} \mathrm{C} \mathrm{min}^{-1}$ then to $300^{\circ} \mathrm{C} @ 4^{\circ} \mathrm{C}$ min $^{-1}$ (isothermal for $20 \mathrm{~min}$ ). Identification of the Me,Et and Et,Et components (structures in Fig. 1) was performed by comparison with standards obtained by oxidation of aetioporphyrin III and octaethylporphyrin, respectively. Other maleimides were identified by comparing retention times and mass spectra with those observed by Grice et al. $(1996,1997)$.

\section{Results}

\section{The Toarcian $O A E$}

Lower Toarcian organic-rich black shales are geographically widespread, occurring in Europe, North America, Asia, Japan, Australia and Madagascar (Jenkyns 1988; Jenkyns et al. 2002). Because of their similarity to Cretaceous black shales, the Toarcian organic-rich sediments are also thought to record an OAE (Jenkyns 1985, 1988). The event apparently lasted $c$.
0.5 Ma (Jenkyns 1988), spanning the falciferum ammonite biozone (specifically, the exaratum subzone) and is associated with emplacement of a large igneous province (Pálfy \& Smith 2000; Jones \& Jenkyns 2001) and relatively high sea level (Haq et al. 1987). Toarcian OAE sediments are characterized by a negative followed by a positive excursion in the carbon-isotope composition of organic matter and carbonate (Jenkyns \& Clayton 1986, 1997; Hollander et al. 1991). The positive excursion is typically ascribed to the burial of ${ }^{13} \mathrm{C}$-depleted organic matter and the consequential ${ }^{13} \mathrm{C}$ enrichment in surface-water dissolved inorganic carbon. The negative excursion has been attributed to a number of mechanisms, but its occurrence in terrestrial carbon (Hesselbo et al. 2000; Beerling et al. 2002) indicates that it records a change in the global ocean-atmosphere carbon reservoir. Another characteristic of the Toarcian OAE is the extinction and reduction in diversity of organisms such as bivalves, dinoflagellates, ostracodes, gastropods, foraminifera and ammonites (Jenkyns 1985, 1988; Little \& Benton 1995).

We examined maleimide distributions in dark marls of the Marche-Umbria basin (Valdorbia near Gubbio, Marche-Umbria, Italy), which, during Toarcian times, represented part of the continental margin or proto-continental margin of the Tethys Ocean (Fig. 2). Previous work at this site (Jenkyns \& Clayton 1986) revealed a positive excursion in carbonate $\delta^{13} \mathrm{C}$ values above the black shales, and complete stratigraphic details have been previously published (Monaco et al. 1994; Pettinelli et al. 1995). A variety of maleimides is present in VAL1 (lowermost in section) and VAL4-7, including Me,H, Me,Me, Me,Et, Me, $i$-Pr, $\mathrm{Et}, \mathrm{Et}, \mathrm{Me}, n-\mathrm{Pr}, \mathrm{Me}, i$-Bu and $\mathrm{Me}, n-\mathrm{Bu}$ components. A summary of these data is shown in Table 1 (in all cases, sample numbers referred to in the text and Table 1 increase up-section). Samples VAL2 and VAL3 contain most of the same components but lack $\mathrm{Me}, i$ - $\mathrm{Bu}$ maleimide. As typically observed, the distributions are dominated by components of phytoplankton origin, i.e. Me, $\mathrm{H}$, $\mathrm{Me}, \mathrm{Me}$ and $\mathrm{Me}$,Et maleimides. The $\mathrm{Me}, i-\mathrm{Bu} / \mathrm{Me}$,Et ratio is highest in VAL7 (Fig. 3) and, although the sampling is sparse, there appears to be an up-section increase in the ratio. Similarly, high molecular weight porphyrins (V-VII), inferred to derive from $\mathrm{Bchl} d$ or $e$, are absent from VAL2,3, and their ratios relative to desoxophylloerythroaetioporphyrin (DPEP; IV, derived from $\mathrm{Chl} a$ ) increase up-section.

In addition, high-molecular-weight porphyrins (V-VII), inferred to derive from $\mathrm{Bchl} d$ or $e$, are present in a variety of other southern and northern European sites. These porphyrins occur in a black shale (total organic carbon (TOC) 3.3\%; total

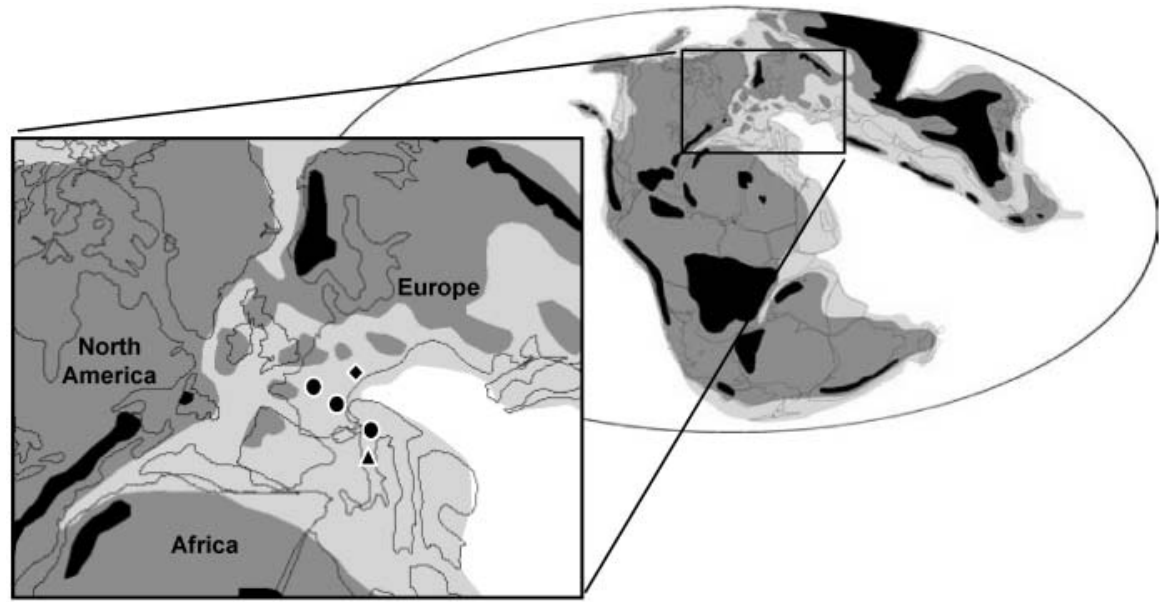

Fig. 2. Maps showing palaeogeography during the Toarcian OAE (adapted from Scotese (2001)) and the location of the Valdorbia site $(\mathbf{\Lambda})$. Also shown are sites where high-molecular-weight porphyrins thought to derive from green sulphur bacteria $(\bullet)$ have been recovered in Toarcian sediments. $\downarrow$, Posidonienschiefer, SW Germany, where high molecular weight porphyrins and derivatives of isorenieratene and chlorobactene have been found. 
Table 1. Geochemical data for samples; for each site, samples are listed in stratigraphic order

\begin{tabular}{|c|c|c|c|c|c|}
\hline Sample & $\begin{array}{l}\text { TOC } \\
(\%)\end{array}$ & $\begin{array}{l}\text { Sulphur } \\
(\%)\end{array}$ & $\begin{array}{c}\text { Free } \mathrm{Me}, i-\mathrm{Bu} \\
\text { maleimide }\end{array}$ & $\begin{array}{c}\text { Me, } i \text {-Bu from } \\
\text { porphyrin } \\
\text { oxidation }\end{array}$ & $\begin{array}{l}\text { Porphyrin } \\
\text { evidence for } \\
\text { PZE }\end{array}$ \\
\hline \multicolumn{6}{|c|}{$C / T$ boundary } \\
\hline $367-2$ & 29.5 & 8.1 & + & n.d. & + \\
\hline $367-3$ & 26.3 & 6.1 & + & n.d. & + \\
\hline 368 & 9.6 & 2.0 & + & + & + \\
\hline 603B-3 & 7.5 & 2.0 & + & n.d. & n.d. \\
\hline 603B-5 & 3.9 & 1.8 & + & n.d. & n.d. \\
\hline 551 & 5.8 & 2.1 & + & n.d. & n.d. \\
\hline GCLB-2 & 16.1 & 1.5 & + & n.d. & + \\
\hline GCLB-1 & 18.5 & 2.1 & + & n.d. & + \\
\hline F1 & 31.2 & 4 & + & + & + \\
\hline FOS5 & 25.3 & 5.8 & - & n.d. & + \\
\hline FOS4 & 29.7 & 4.9 & - & n.d. & + \\
\hline FOS3 & 21.1 & 2.9 & - & n.d. & + \\
\hline FOS2 & 15.3 & 1.9 & - & n.d. & - \\
\hline FOS1 & 22.4 & 4.7 & + & n.d. & + \\
\hline MP8 & 11.2 & 0.6 & + & n.d. & + \\
\hline MP7 & 18.3 & 2.5 & - & n.d. & n.d. \\
\hline MP6 & 22.0 & 3.1 & - & n.d. & + \\
\hline MP5 & 20.8 & 2.5 & + & n.d. & + \\
\hline MP4 & 11.0 & 1.2 & + & n.d. & + \\
\hline MP3 & 16.8 & 1.9 & + & n.d. & + \\
\hline MP2 & 17.2 & 1.7 & + & n.d. & n.d. \\
\hline MP1 & 2.3 & 1.2 & - & n.d. & n.d. \\
\hline $\mathrm{CG}$ & n.d. & n.d. & + & n.d. & + \\
\hline CGQ3 & 5.7 & 1.0 & - & n.d. & - \\
\hline CGQ2 & 16.3 & 2.9 & - & n.d. & + \\
\hline CGQ1 & 12.4 & 1.3 & + & n.d. & + \\
\hline BG4 & 13.4 & 0.9 & + & + & + \\
\hline BG3 & 7.7 & 0.5 & + & + & + \\
\hline BG2 & 8.9 & 0.5 & - & n.d. & + \\
\hline BG1 & 6.7 & 0.3 & - & n.d. & - \\
\hline GU1 & 4.8 & 0.2 & + & n.d. & + \\
\hline OB6 & n.d. & n.d. & + & n.d. & + \\
\hline OB17 & n.d. & n.d. & + & n.d. & + \\
\hline OB28 & n.d. & n.d. & - & n.d. & - \\
\hline OB68 & n.d. & n.d. & - & n.d. & - \\
\hline OB $71 / 72$ & n.d. & n.d. & - & n.d. & - \\
\hline $763 \mathrm{C} 1$ & 2.9 & 1.3 & + & n.d. & n.d. \\
\hline $763 \mathrm{C} 2$ & 25.9 & 1.6 & + & n.d. & n.d. \\
\hline $763 \mathrm{C} 3$ & 9.0 & 3.0 & + & n.d. & n.d. \\
\hline \multicolumn{6}{|c|}{ Early Aptian } \\
\hline GAC6 & 3.87 & 1 & + & n.d. & + \\
\hline GAC5 & 2.64 & 1.1 & - & n.d. & - \\
\hline GAC4 & 0.97 & 0.4 & - & n.d. & - \\
\hline GAC3 & 0.87 & 0.6 & - & n.d. & - \\
\hline GAC2 & 5.16 & 1.0 & + & n.d. & + \\
\hline GAC1 & 3.54 & 0.9 & + & n.d. & + \\
\hline \multicolumn{6}{|l|}{ Toarcian } \\
\hline VAL7 & 2.66 & 0.1 & + & n.d. & n.d. \\
\hline VAL6 & n.d. & n.d. & + & n.d. & n.d. \\
\hline VAL5 & n.d. & n.d. & + & n.d. & + \\
\hline VAL4 & 6.52 & 0.4 & + & n.d. & + \\
\hline VAL3 & n.d. & n.d. & - & n.d. & - \\
\hline VAL2 & 3.87 & 0.6 & - & n.d. & - \\
\hline VAL1 & n.d. & n.d. & + & n.d. & + \\
\hline
\end{tabular}

PZE, photic-zone euxinia. +, Compound present; criterion is the presence of a peak at the appropriate retention time, from which the mass spectrum of $\mathrm{Me}, i$-Bu maleimide can be obtained; this is dependent on both the compound's abundance and co-elution with other components.-, Compound not detected. n.d., not determined.

sulphur $0.42 \%$ ) that is exposed at Longarone, north of Venice (palaeoceanographically in the Belluno Trough to the east of the Trento Plateau) and that was deposited at a palaeodepth of $c$. $1 \mathrm{~km}$ (locality details given by Jenkyns et al. (1985)). These compounds were also identified in the coeval 'Schistes Carton' of the Paris Basin at sites near Semécourt (a black shale with
TOC $6.8 \%$ ) and Colombotte (black shale with TOC $7.9 \%$ ); unfortunately, the specific horizon of the $30 \mathrm{~m}$ thick Schistes Carton from which these samples were collected is not known. Finally, compounds V-VII are present in two dark grey laminated shales (TOC $11.5 \%$ and $11.9 \%$ ) from the Middle Lias $\epsilon$ of the southern German Basin Posidonia Shale (Posido- 

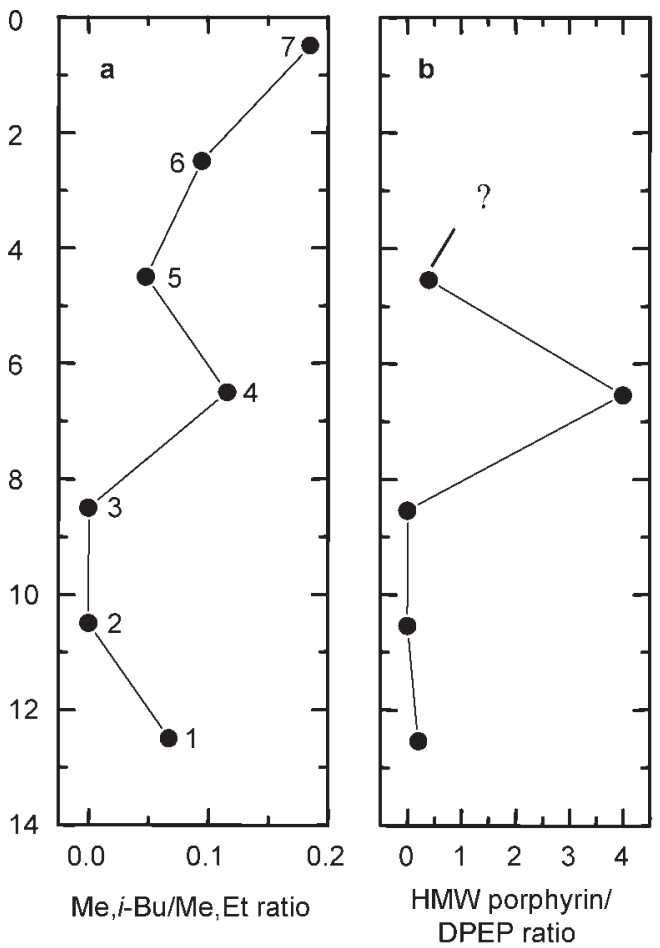

Fig. 3. Depth profiles (in metres from top of the black marl interval exposed in outcrop) of the $\mathrm{Me}, i$-Bu/Me,Et maleimide ratio (a) and the abundance of high molecular weight (HMW) porphyrins (V-VII), inferred to derive from $\mathrm{Bchl} d$ or $e$, normalized against that of DPEP (b). The HMW porphyrin/DPEP ratios are not shown for VAL1 and VAL2 because of insufficient material for porphyrin analysis. Numbers beside data points refer to the sample names in Table 1 and the text.

nienschiefer, specifically, the Unterer Schiefer, horizon II/4 near Holzmaden; Eckardt et al. 1991; Waring 1991). The abundances of $\mathbf{V}-$ VII relative to DPEP are higher in the Schistes Carton and the Posidonia shale than in their southern European equivalents.

\section{The Aptian OAEla (Selli Event)}

OAE1a, the earliest of the Cretaceous OAEs defined by Arthur et al. (1990), occurred during the early Aptian (Schlanger \& Jenkyns 1976; Jenkyns 1980; Sliter 1989; Görür 1991; Bralower et al. 1994). Maleimide distributions were determined for black shales spanning the Livello Selli horizon at Gorgo a Cerbara, situated near Gubbio in the Umbria-Marche region of Italy
(Cresta et al. 1989; Coccioni et al. 1992; Fig. 4). The Livello Selli is part of the Scisti a Fucoidi formation, which comprises cyclical interbeds of laminated, $<10 \mathrm{~cm}$ thick black shales devoid of benthic foraminifera (Coccioni et al. 1992) and greenish grey to pink, homogeneous marls and limestones. Bulk carbonate and organic matter $\delta^{13} \mathrm{C}$ values exhibit positive $2 \%$ shifts across the Livello Selli, as has been observed elsewhere at correlative horizons (Pratt \& King 1986; Weissert 1989; Menegatti et al. 1998; Bellanca et al. 2002). Samples GAC1 (lowermost), 2 and 6 contain a variety of free maleimides, including Me,H, Me,Me, Me,Et, Me, $i$-Pr, Et,Et, Me, $n$-Pr, Me, $i$ $\mathrm{Bu}$ and $\mathrm{Me}, n-\mathrm{Bu}$ components. The distributions in GAC3-5 differ in that they contain the majority of the above components but lack the specific $\mathrm{Me}, i$-Bu maleimide. Consistent with the occurrence of $\mathrm{Me}, i$-Bu maleimide, HMW porphyrins of inferred Chlorobiaceae origin are present in samples GAC1, 2 and 6 but not in GAC3, 4 and 5.

\section{The Cenomanian-Turonian boundary OAE2 (Bonarelli Event)}

The Cenomanian-Turonian $(\mathrm{C} / \mathrm{T})$ boundary OAE occurred $c$. 93.5 Ma ago (Gradstein et al. 1999) and is characterized by nearly synchronous organic-rich horizons around the world (Schlanger \& Jenkyns 1976: Schlanger et al. 1987), particularly in the proto-North Atlantic, where organic carbon contents commonly exceed $30 \%$. The duration of the event was probably less than 0.5 Ma (Kuhnt et al. 1997) and it was associated with a significant mass extinction across disparate marine realms (e.g. Kuhnt et al. 1986). The OAE is further defined by a positive carbon-isotope excursion recorded by carbonate (c. 2.5\%; Scholle \& Arthur 1980; Arthur et al. 1988; Jenkyns et al. 1994), and marine and terrestrial organic carbon (c. 4\%; Arthur et al. 1988; Hayes et al. 1990; Hasegawa 1997; Tsikos et al. 2004). The difference between the inorganic and organic carbon-isotope records has been attributed to a decrease in $p \mathrm{CO}_{2}$ (and, thus, carbon-isotope fractionation by marine algae) as a result of extensive removal of carbon from the ocean-atmosphere reservoir (Arthur et al. 1988; Freeman \& Hayes 1992; Kuypers et al. 1999). Thus, the C/T boundary OAE could have caused a brief period of global cooling (e.g. Jenkyns et al. 1994; Jenkyns 2003); none the less, this event occurred during a period characterized by generally very high global temperatures (e.g. Clarke \& Jenkyns 1999). We investigated both free maleimides and those released by porphyrin oxidation in $\mathrm{C} / \mathrm{T}$ boundary black shales from the North Atlantic, the Northern Tethys and an area off NW Australia (Fig. 5).

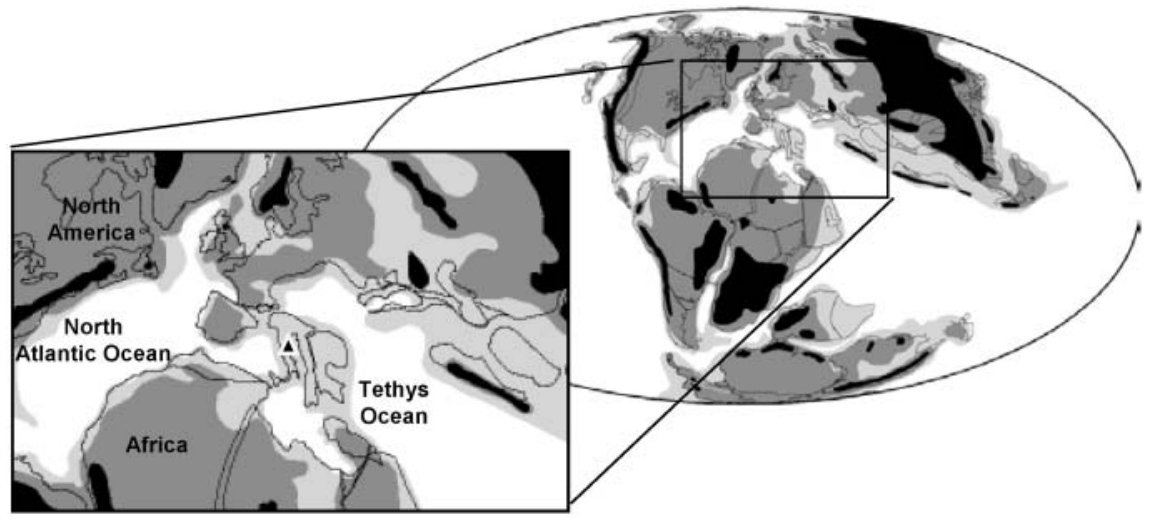

Fig. 4. Maps showing palaeogeography during the Aptian OAE1a (adapted from Scotese (2001)) and the location of the Gorgo a Cerbara site $(\mathbf{\Lambda})$. 


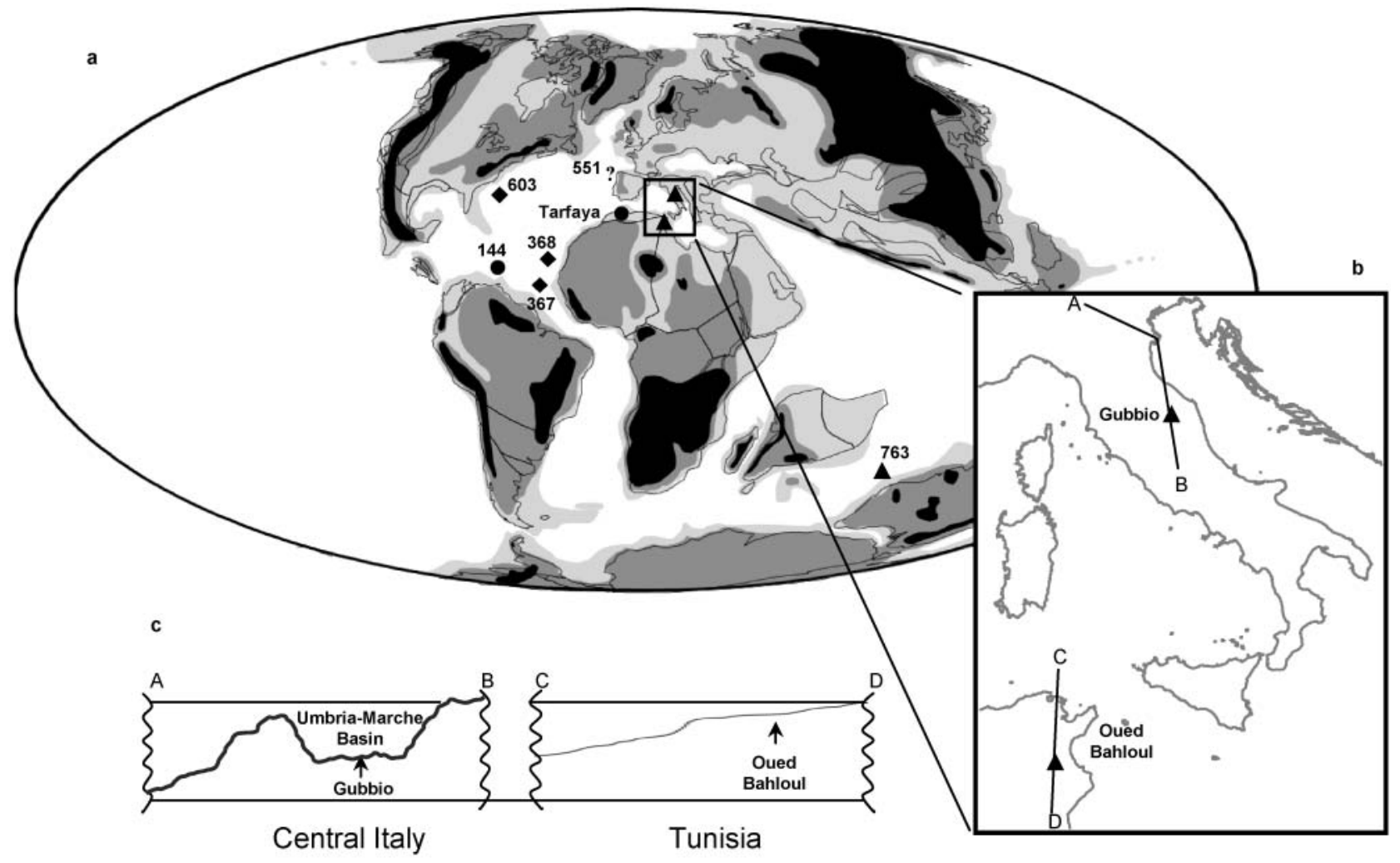

Fig. 5. Maps (a and b) and vertical profiles (c) showing palaeogeography during the Cenomanian-Turonian OAE (adapted from Farrimond (1987) and Scotese (2001)) and the locations of North Atlantic, Tethyan and Indian Ocean sites examined. Also shown are sites where previous workers examined the distributions of isorenieratene derivatives. $\mathbf{\Delta}$, Sites where $\mathrm{Me}, i-\mathrm{Bu}$ is present but isorenieratene derivatives have either not been examined (Oued Bahloul and 763) or not found (Gubbio); sites where both Me,i-Bu maleimide and isorenieratene derivatives have been found; $\bullet$, sites where isorenieratene derivatives have been found but maleimides have not been examined. Site 551 is represented by a question mark because Me, $i$-Bu abundances are at the limits of detection, and therefore evidence for euxinic conditions in the photic zone is equivocal.

Northern Atlantic. Deep Sea Drilling Project (DSDP) Sites 367 and 368 are located on the Cape Verde Basin (Leg 41, Site 367, Core 18) and Cape Verde Rise (Leg 41, Site 368), situated off the coasts of Senegal and Gambia, respectively. Geochemical data on these cores have been extensively published (Brumsack \& Thurow 1986; de Graciansky et al. 1986b; Herbin et al. 1986) and indicate that $\mathrm{C} / \mathrm{T}$ boundary intervals from both cores are characterized by high TOC contents and hydrogen indices. From Site 367 , core 18, two samples were analysed: Section 2, interval 91-95 cm (sample 367-2); and Section 3, interval 91-95 cm (sample 367-3). From Site 368, only one sample was examined: Core 63, Section 3, interval 120-125 cm (sample 368). Free maleimides are abundant in all three samples, with $\mathrm{Me}, \mathrm{Me}$, $\mathrm{Me}, \mathrm{Et}, \mathrm{Et}, \mathrm{Et}, \mathrm{Me}, n-\mathrm{Pr}$ and $\mathrm{Me}, i$-Bu components all present. Oxidation of the demetallated vanadyl porphyrins in sample 368 revealed the same components, albeit with somewhat different distributions. In all cases, maleimide distributions are dominated by the Me,Et component with lesser abundances of the Me,Me component. Consistent with the presence of maleimides of inferred Chlorobiaceae origin, cycloalkanoporphyrins inferred to derive from Bchls $d$ and $e$ were also observed (Fig. 1, I). To evaluate further the source assignments, GC-IRMS analyses were performed on 367-2 and 367-3 maleimides. Me,Et maleimide $\delta^{13} \mathrm{C}$ values are $-21.2 \%$ and $-21.6 \%$ in the two samples, respectively, and $\mathrm{Me}, i$-Bu maleimide $\delta^{13} \mathrm{C}$ values are $-7.8 \%$ and $-7.5 \%$, respectively; this $>12 \%$ difference reflects the reduced carbon-isotope fractionation associated with carbon assimilation via the reversed tricarboxylic acid (TCA) cycle and confirms a marine algal source for Me,Et maleimide and a green sulphur bacterial source for $\mathrm{Me}, i$-Bu maleimide (e.g. Sirevag et al. 1977).

DSDP Site 603B (Leg 93) is situated on the continental rise off Cape Hatteras (NE USA), and sections of C/T boundary age are developed as black organic-rich claystones. The organic-rich sediments of the C/T interval (specific samples are: Core 34, Section 3, interval 65-70 cm (sample 603B-1); and Core 34, Section 5, interval 91-95 cm (sample 603B-2)) are characterized by moderate hydrogen indices (c. $400 \mathrm{mg}$ hydrocarbon $\mathrm{g}^{-1} \mathrm{C}$ ), and organic matter is inferred to derive from a combination of unicellular algae (Rullkötter \& Mukhopadhyay 1986) and bacterial matter (Farrimond et al. 1986). Such an assemblage is unusual as this site is typically dominated by terrigenous sources of organic matter (Tissot et al. 1980). Free maleimides were present in both samples and include the $\mathrm{Me}, \mathrm{H}, \mathrm{Me}, \mathrm{Me}, \mathrm{Me}, \mathrm{Et}$, $\mathrm{Me}, i$-Pr, Et,Et, Me, $n$-Pr, Me, $i$-Bu and Me, $n$-Bu components. As with other $\mathrm{C} / \mathrm{T}$ sediments, the Me,Et component was the most abundant maleimide in both samples.

DSDP Site 551 is located on the Goban Spur SW of Ireland, and the $\mathrm{C} / \mathrm{T}$ boundary interval is represented by a thin black shale enclosed by white chalks. The shale is characterized by high TOC contents (c. 10\% after Waples \& Cunningham 1985) and contains a high proportion of siliceous material and almost 
no carbonate (de Graciansky et al. 1986b). It is thought to have been deposited at a depth of c. $1300 \mathrm{~m}$ (de Graciansky et al. $1986 a$ ). Only one sample of the black shale was analysed; free maleimides were recovered with the Me,Et component being most abundant, the $\mathrm{Me}, \mathrm{Me}$ and $\mathrm{Me}, \mathrm{H}$ components being present in subordinate abundances, and the Me, $i$-Pr, Et,Et, Me, $n$-Pr, $\mathrm{Me}, i-\mathrm{Bu}$ and $\mathrm{Me}, n-\mathrm{Bu}$ components occurring as very minor components.

The Tethyan Ocean. The Livello Bonarelli (Bonarelli Level) in the Gubbio area of Italy is an organic-rich $c .1 \mathrm{~m}$ thick bed consisting of radiolarian sand and interbedded laminated black shale (Arthur \& Premoli Silva 1982; Schlanger et al. 1987). This bed lies immediately below the $\mathrm{C} / \mathrm{T}$ boundary and effectively separates the Scaglia Bianca and Scaglia Rossa Formations. The Livello Bonarelli, which is carbonate-free and pyritic, has TOC contents $>25 \%$ in some of its organic-rich levels (Tsikos et al. 2004). The organic matter, inferred to be of largely marine origin, occurs mainly as compressed amorphous wisps. Black shales from the Livello Bonarelli were collected from outcrops throughout the Gubbio area of Italy and their maleimide distributions were measured.

Two outcrop samples were analysed from the Gorgo a Cerbara (GCLB-1 and 2, the latter collected and described by Farrimond (1987)), situated by a road near Piobbico in the valley of the Torrente Candigliano (Cresta et al. 1989). Farrimond (1987) reported that the organic matter is composed entirely of amorphous material of low thermal maturity. The free maleimides of both samples include the Me,H, Me,Me, Me,Et, Me, $i$-Pr, Et,Et, $\mathrm{Me}, n$-Pr, Me, $i$-Bu and Me, $n$-Bu components, with the Me,Et and $\mathrm{Me}, \mathrm{Me}$ being the most abundant. The presence of $\mathrm{Me}, i-\mathrm{Bu}$ maleimide in these (and following samples) is the first evidence for photic-zone euxinic conditions during deposition of the Livello Bonarelli.

Six samples, five of which were collected for this study (FOS1-5) and one (F1) that was collected previously (Farrimond 1987), were examined from the Livello Bonarelli, exposed in vertical outcrop near Fosto on the road between Piobbico and Secchiano (Cresta et al. 1989). The organic matter consists of amorphous, presumably marine, material with sparse palynomorphs and is thermally immature (Farrimond 1987; Farrimond et al. 1990). The free maleimides in FOS1 and F1 include the $\mathrm{Me}, \mathrm{H}, \mathrm{Me}, \mathrm{Me}, \mathrm{Me}, \mathrm{Et}, \mathrm{Me}, i$-Pr, Et,Et, Me, $n$-Pr, Me, $i$-Bu and $\mathrm{Me}, n$-Bu components. In contrast, maleimides in FOS2-5 lack the $\mathrm{Me}, i$-Bu component. To confirm sources of maleimides, the porphyrins of F1 were combined into one fraction and oxidized. Like the free maleimides, those formed by porphyrin oxidation have a distribution consisting of the Me,H, Me,Me, Me,Et, Me, $i$ $\mathrm{Pr}, \mathrm{Et}, \mathrm{Et}, \mathrm{Me}, n-\mathrm{Pr}, \mathrm{Me}, i-\mathrm{Bu}$ and $\mathrm{Me}, n$-Bu components.

Eight black shale samples were obtained from a $90 \mathrm{~cm}$ section of the Livello Bonarelli at an outcrop near the top of Monte Petrano on a dirt road SW of Cagli (MP1-8). Here, the Livello Bonarelli is characterized by black shales interbedded with siliceous radiolarian sandstones, clayey radiolarian sandstones and pyrite concretions. The free maleimides in MP2-6 and 8 include the Me,Et (most abundant), Me,Me, Me,H, Me, $n$-Pr, Et,Et, $\mathrm{Me}, n-\mathrm{Bu}, \mathrm{Me}, i$-Pr and $\mathrm{Me}, i$ - $\mathrm{Bu}$ components. In contrast, MP1, 6 and 7 lack the Me,i-Bu maleimide. The Monte Petrano samples were further examined using GC-IRMS to determine the stable carbon-isotope composition of the Me,Et component (Fig. 6). $\delta^{13} \mathrm{C}$ values range from -23 to $-20 \%$, about $5 \%$ higher than $\delta^{13} \mathrm{C}$ values obtained for bulk Ni-porphyrin fractions isolated from $\mathrm{C} / \mathrm{T}$ boundary sediments (Greenhorn Formation) of the Cretaceous Western Interior Seaway (Hayes et al. 1990).

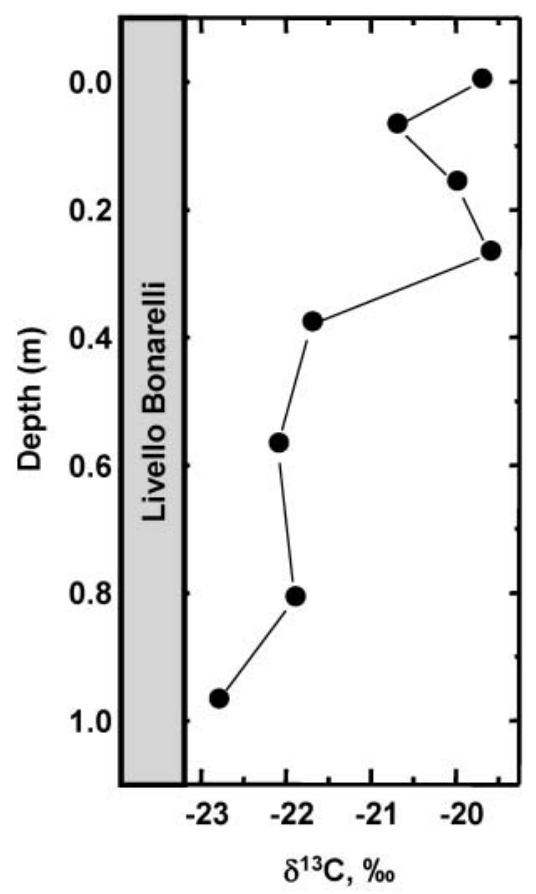

Fig. 6. Depth profile showing Me,Et maleimide $\delta^{13} \mathrm{C}$ values through the Livello Bonarelli cropping out at the Monte Petrano section in the Gubbio region of Italy.

Potentially, this difference reflects lower $\left[\mathrm{CO}_{2(\mathrm{aq})}\right]$ and/or higher algal growth rates in the Tethys than in the Cretaceous Western Interior Seaway (e.g. Bidigare et al. 1997). However, the two records are similar in that they both exhibit the positive carbonisotope excursion commonly observed in $\mathrm{C} / \mathrm{T}$ boundary sediments. Our record, both in terms of absolute values and temporal trends, is also consistent with inorganic and organic carbonisotope analyses of the Livello Bonarelli (Tsikos et al. 2004). As $\delta^{13} \mathrm{C}$ values of Me,Et maleimide are easy to determine as a result of the ease of maleimide preparation and the lack of significant co-elution during GC, this compound could be useful in chemostratigraphy where other diagnostic biomarkers are absent.

Three samples (CGQ1-3) were analysed from the north end of a quarry complex in the Contessa Gorge NW of Gubbio. An additional sample (CG1) collected earlier from the same locality (Farrimond 1987) was also analysed. The organic matter in CG1 is amorphous, excepting uncommon woody fragments, and is slightly more thermally mature than the organic matter in the more northern sites (Farrimond 1987; Farrimond et al. 1990). CGQ1 and CG1 both contain free Me, $n-\mathrm{Pr}$ and $\mathrm{Me}, i-\mathrm{Bu}$ maleimides as well as a suite of the more common maleimides; in contrast, CGQ2 and 3, although characterized by similar distributions, did not contain the $\mathrm{Me}, i$-Bu component.

The top $90 \mathrm{~cm}$ of the Bonarelli Horizon is exposed in the Bottaccione Gorge $3 \mathrm{~km}$ NE of Gubbio. Four samples (BG1-4) were collected, one each from four black bands interbedded with radiolarian-rich siliceous material. A fifth sample, GU1, collected from the same site by Farrimond (1987) was also analysed. The free maleimides of GU1, BG3 and BG4 had similar distributions, with the $\mathrm{Me}, \mathrm{H}, \mathrm{Me}, \mathrm{Me}, \mathrm{Me}, \mathrm{Et}, \mathrm{Me}, i$-Pr, Et,Et, Me, $n$-Pr, Me, $i$-Bu and $\mathrm{Me}, n-\mathrm{Bu}$ components present. Similar distributions were obtained by oxidation of the combined demetallated nickel and vanadyl porphyrin fractions of BG3 and BG4. In contrast, the 
free maleimides from BG1 and BG2 consist of the Me, $\mathrm{H}, \mathrm{Me}, \mathrm{Me}$ and $\mathrm{Me}, \mathrm{Et}$ components with relatively low abundances of the $\mathrm{Et}, \mathrm{Et}$ and $\mathrm{Me}, n$-Pr maleimides. $\mathrm{Me}, i$-Bu and $\mathrm{Me}, n$-Bu maleimides were not detected.

The Bahloul Formation, outcropping near Oued Bahloul in NE Tunisia, is a $20-50 \mathrm{~m}$ unit composed of interbedded bituminous marls and limestones. The sediments were deposited in relatively deep water (Herbin et al. 1986; Schlanger et al. 1987), and the organic matter in the bituminous beds is mainly of marine origin with minor terrigenous input (Farrimond et al. 1990). Hydrogen indices range from 260 to $670 \mathrm{mg}$ hydrocarbon $\mathrm{g}^{-1}$ TOC (Herbin et al. 1986). Five samples were analysed (OB 71/72, 68, 28, 17, 6). The free maleimides in sample OB17 and OB6 include the $\mathrm{Me}, \mathrm{H}, \mathrm{Me}, \mathrm{Me}, \mathrm{Me}, \mathrm{Et}, \mathrm{Me}, i$-Pr, Et,Et, Me, $n$-Pr, Me, $i$-Bu and $\mathrm{Me}, n$-Bu components. However, the $\mathrm{Me}, i$-Bu and $\mathrm{Me}, n-\mathrm{Bu}$ components were not observed in OB71/72, OB68 and OB28.

Exmouth Plateau, off Western Australia, Indian Ocean. The Exmouth Plateau, considered as formerly part of the eastern extremity of the Tethys, is situated on the NW continental margin of Australia (Fig. 5). Samples were collected from Ocean Drilling Program (ODP) Hole 763C from two thin layers of black shale, $4 \mathrm{~cm}$ and $12 \mathrm{~cm}$ thick, separated by green mottled claystone (Section 2R-1, interval 63-66 cm (sample 763C1) from the $4 \mathrm{~cm}$ layer; Section 2R-1, interval $29-33 \mathrm{~cm}$ (sample $763 \mathrm{C} 2$ ); Section $2 \mathrm{R}-1$, interval $23-26 \mathrm{~cm}$ (sample 763C3); and Section 2R-1, interval $20-23 \mathrm{~cm}$ (sample 763C4) from the $12 \mathrm{~cm}$ layer). The sediments are thought to have been deposited at a palaeo-depth of 500-1000 m (Haq et al. 1992). Previous analyses of similar samples revealed TOC contents exceeding 25\% (Rullkötter et al. 1992), whereas stratigraphically equivalent sediments at Site $762,84 \mathrm{~km}$ to the north, do not exceed $2 \%$ (Haq et al. 1990). Organic matter, consisting of structurally degraded bituminite, is inferred to be of marine origin, has hydrogen indices of $c .450 \mathrm{mg}$ hydrocarbon $\mathrm{g}^{-1} \mathrm{C}_{\mathrm{org}}$, and is thermally immature (Rullkötter et al. 1992).

Sample $763 \mathrm{C} 1$ from the (lower) $4 \mathrm{~cm}$ thick black shale contains free Me,H, Me,Me, Me,Et, Me,i-Pr, Et,Et, Me, $n$-Pr, $\mathrm{Me}, i-\mathrm{Bu}$ and $\mathrm{Me}, n-\mathrm{Bu}$ maleimides. As is commonly observed, the Me,Et and Me,Me maleimides are the most abundant, but Et,Et maleimide is also present in significant relative abundances. Samples $763 \mathrm{C} 2$ and $763 \mathrm{C} 3$ from the (upper) $12 \mathrm{~cm}$ thick layer contain the same free maleimides as sample $763 \mathrm{C} 1$ with the exception of the Me, $n$-Bu component, which is absent. Differences in maleimide distributions include relatively higher $\mathrm{Me}, i$ $\mathrm{Bu}$ abundances and lower Et,Et abundances in samples $763 \mathrm{C} 2$ and $763 \mathrm{C} 3$ compared with $763 \mathrm{C} 1$. In sample $763 \mathrm{C} 4$, only the $\mathrm{Me}, \mathrm{H}, \mathrm{Me}, \mathrm{Me}, \mathrm{Me}, \mathrm{Et}$, Et,Et and $\mathrm{Me}, n-\mathrm{Pr}$ components were detected.

\section{Discussion}

All of the porphyrin and maleimide data are summarized in Table 1 and show evidence for photic-zone euxinic conditions during all three OAEs investigated.

\section{Toarcian}

The first evidence for the presence of Chlorobiaceae and photiczone euxinic conditions during the Toarcian OAE was obtained from the presence of molecular fossils of the pigments isorenieratene and chlorobactene, biomarkers for the green and brown strains of green sulphur bacteria, respectively (Imhoff 1995), in the SW German Posidonienschiefer (Schouten et al. 2000). Our results confirm these observations. Moreover, the presence of green sulphur bacterial biomarkers in sediments from the Belluno Basin and Marche-Umbria (Valdorbia) extends the evidence for photic-zone euxinic conditions to southern Europe and, critically, the margins of the Tethyan Ocean. None the less, photic-zone euxinic conditions were probably neither as widespread nor as prolonged on the Tethyan margin as in the more northern epicontinental seas. Some Valdorbia samples contain no green sulphur bacterial biomarkers, and high-molecular-weight porphyrin to DPEP ratios are lower in Italian sections than in equivalent French and German black shales. These geographical variations in water-column redox conditions probably affected organic carbon preservation; indeed, southern European and north African sites (Italy, Greece, Tunisia) are characterized by lower organic carbon contents than northern European sites (Jenkyns 1985, 1988; Baudin et al. 1990), and marine organic matter in the Belluno Trough Toarcian black shales is degraded (Farrimond et al. 1989), suggesting at least intermittent oxygenation of the water column during deposition

Photic-zone euxinic conditions also apparently changed during the OAE. The relative abundances of $\mathrm{Me}, i$ - $\mathrm{Bu}$ maleimide in the Marche-Umbria Basin increase up-section (Fig. 3) as do abundances of diagnostic isorenieratene and chlorobactene derivatives (Schouten et al. 2000), with notably higher abundances occurring in the falciferum ammonite zone than in the tenuicostatum zone. This increase suggests that the duration of euxinic episodes in near-surface waters increased or that euxinic waters shoaled during the event, perhaps reflecting stabilization of the water column, and it is consistent with models in which black-shale deposition is caused by the impingement of a shoaling oxygenminimum zone (as a result of either enhanced productivity or marine transgression) onto continental margin sediments (Jenkyns 1985, 1988; Jenkyns et al. 2001). In such a model, only during times of the most intense productivity would euxinic conditions have extended into the photic zone and resulted in the accumulation of green sulphur bacterial biomarkers. This model is also consistent with nitrogen-isotope evidence from Toarcian black shales in Italy and the UK indicating that, at times, denitrification rather than sulphate reduction was the dominant process by which organic matter was oxidized in the water column (Jenkyns et al. 2001).

\section{Aptian \\ There is no previous evidence for photic-zone euxinic conditions during Aptian OAE1a; here, however, a combination of malei- mide and porphyrin data indicates that such conditions did occur at least periodically during deposition of the Livello Selli. Given that only one locality was investigated, it is difficult to interpret these observations in the context of Aptian oceanography; how- ever, the variable occurrence of biomarkers for green sulphur bacteria, similar to that observed in the Toarcian Valdorbia section, indicates that photic-zone euxinic conditions were episodic and perhaps related to a fluctuating oxygen-minimum zone.}

\section{Cenomanian-Turonian boundary}

Previous work has clearly revealed that photic-zone euxinia was a persistent and important characteristic of the North Atlantic during the C/T boundary OAE. Sinninghe Damsté \& Köster (1998) detected isorenieratene in the $\mathrm{C} / \mathrm{T}$ boundary horizons at DSDP Sites 144, 367 and 368, and in a core from Morocco (Tarfaya). These results were confirmed and extended by Kuypers 
et al. (2002), who determined that these conditions also preceded the OAE. Sinninghe Damsté \& Köster (1998) did not detect isorenieratene derivatives at DSDP Site 603B; however, subsequent work (Kuypers 2001) revealed that isorenieratene is indeed present in these sediments, albeit at significantly lower concentration. Sinninghe Damsté \& Köster (1998) also did not detect diagnostic isorenieratene derivatives at DSDP Site 551 nor in the Livello Bonarelli.

Consistent with these results, we observed $\mathrm{Me}, i$-Bu maleimide in $\mathrm{C} / \mathrm{T}$ boundary sediments of DSDP Sites 367, 368 and 603B and the Oued Bahloul (Tunisia). However, we also detected Me, $i$ $\mathrm{Bu}$ maleimide in $\mathrm{C} / \mathrm{T}$ boundary sediments from DSDP Site 551 and in the Livello Bonarelli, where diagnostic isorenieratene derivatives are absent; we ascribe this discrepancy to a variety of factors. First, aryl isoprenoids, degradation products of isorenieratene but also of $\beta$-carotene and, therefore, not diagnostic for green sulphur bacteria (Koopmans et al. 1996), are present in Livello Bonarelli samples. Thus, diagnostic derivatives of isorenieratene could have been thermally degraded whereas more stable maleimides and non-diagnostic aryl isoprenoids have been preserved. Second, the occurrence of $\mathrm{Me}, i$-Bu maleimide in the Livello Bonarelli varies locally within the deposit, suggesting that photic-zone euxinic conditions were episodic. Third, because $\mathrm{Me}, i$ - $\mathrm{Bu}$ maleimide is present in only low concentrations in the DSDP Site 551 shale we are reluctant to interpret its significance. Also, such low abundances indicate that photic-zone euxinic conditions were not pronounced there; thus, all biomarkers for Chlorobiaceae are expected to be present in low abundances, compounding difficulties associated with their detection. Despite these relatively minor discrepancies, the widespread occurrence of $\mathrm{Me}, i-\mathrm{Bu}$, coupled with the detection of certain high-molecularweight porphyrins and, in the case of DSDP Site 367 samples, high $\mathrm{Me}, i$ - $\mathrm{Bu} \delta^{13} \mathrm{C}$ values, confirms previous conclusions that photic-zone euxinic conditions occurred in the southern North Atlantic during the $\mathrm{C} / \mathrm{T}$ boundary OAE. Our work extends these results by identifying evidence for a sulphidic water column in the photic zone of water masses in the Tethyan Ocean (Livello Bonarelli and Oued Bahloul) extending to the present-day Indian Ocean (Exmouth Plateau), the first evidence from the $\mathrm{C} / \mathrm{T}$ boundary OAE for photic-zone euxinic conditions in the Southern Hemisphere.

The recognition of photic-zone euxinic conditions in a number of our samples and those of previous workers is of importance for understanding the chemistry of the ocean during the $\mathrm{C} / \mathrm{T}$ boundary OAE. All of the analysed organic-rich shales exhibit millimetre-scale lamination, implying a lack of bioturbation by benthonic animals and, hence, bottom-water anoxia. Where the same samples show molecular evidence for green sulphur bacteria, it is apparent that free hydrogen sulphide was present in the shallow water column. Although intervening levels of the water column could conceivably have been oxygenated, the most likely hypothesis envisages a stratified water column devoid of oxygen from the photic zone to the sea floor (as proposed, for example, by Sinninghe Damsté \& Köster (1998) and Kuypers et al. (2002)). The origin of such an extensive anoxic-euxinic layer, apparently best developed in peri-equatorial Atlantic DSDP sites, could well lie in enhanced plankton productivity given that equatorial regions today (and presumably in the past) are sites of vigorous upwelling with high nutrient availability in near-surface waters. Consistent with this explanation, Kuypers et al. (2002) suggested that a dramatic increase in TOC contents, isorenieratene derivative abundances and biomarker $\delta^{13} \mathrm{C}$ values at Site 367 during the $\mathrm{C} / \mathrm{T}$ boundary OAE reflects an increase in primary productivity. However, the presence of green sulphur bacterial biomarkers prior to the $\mathrm{C} / \mathrm{T}$ boundary (Kuypers et al. 2002) suggests that euxinic conditions in the photic-zone anoxia were also related to the presence of stagnant water masses trapped by the geometry of the Cretaceous Atlantic. In contrast, for ocean regions in which organic-rich sediments occur on topographic highs but nearby deeper sites are characterized by low organic carbon contents (e.g. DSDP Sites 551 and 763, assuming their stratigraphic records are complete), it seems unlikely that the entire water column was persistently anoxic. Instead, the occurrences of $\mathrm{Me}, i$ - $\mathrm{Bu}$ maleimide and enhanced TOC contents in $\mathrm{C} / \mathrm{T}$ boundary sediments from Sites 551 and 763 probably record regional extension of the oxygen-minimum zone. Thus, we propose that the Cretaceous North Atlantic was a stagnant ocean and an increase in primary productivity at the $\mathrm{C} /$ $\mathrm{T}$ boundary resulted in the expansion of anoxic conditions, represented by more intense photic-zone euxinic conditions in the southern North Atlantic (Kuypers et al. 2002) and incursion of euxinic waters into Tethyan and northernmost Atlantic shallow waters. Given this model, sporadic biomarker evidence for photic-zone euxinic conditions in the Livello Bonarelli of the Umbrian Apennines could reflect the important role of geography in moderating expansion and contraction of anoxic conditions onto the Tethyan margin. Similarly, temporal variations in local productivity probably also influenced the extent of anoxic conditions and are responsible for vertical variations in biomarker evidence for photic-zone euxinia.

\section{Significance for interpreting causes of OAEs}

There are several possible explanations for the occurrence of Chlorobiaceae biomarkers in ancient sediments. First, they could reflect a completely euxinic water column from the sea floor to at least the lower part of the photic zone, as in the Black Sea (Sinninghe Damsté et al. 1993). This palaeoceanographic configuration has been invoked for DSDP Sites 367 and 368 during the $\mathrm{C} / \mathrm{T}$ OAE (Kuypers et al. 2002) on the basis of the co-occurrence of isorenieratene with trace-metal indicators of sedimentary anoxia. Importantly, this is the only situation (e.g. stratified fjords, Black Sea) where green sulphur bacteria are found in modern settings.

Second, Chlorobiaceae could have been present in a productivity-driven oxygen-minimum zone; organic matter would have been preserved in such conditions if the oxygen-minimum zone impinged on the sediments (e.g. continental shelf sites and topographic highs). Free hydrogen sulphide has been observed in the oxygen-minimum zones in the Peru upwelling region (Dugdale et al. 1977) and in the Indian Ocean (Ivanenkov \& Rozanov 1961), but green sulphur bacteria have never been found in such a setting nor have their photosynthetic pigments been found in underlying sediments; thus, such an oxygenminimim zone in Mesozoic oceans must have been more persistently euxinic than those found in the modern ocean.

Third, Chlorobiaceae biomarkers in abyssal marine sediments could have had an allochthonous source. For example, some organic-rich sediments have been attributed to redeposition of slope sediments; thus, the occurrence of $\mathrm{Me}, i$-Bu maleimide in distal sediments would not necessarily record the occurrence of photic-zone euxinic conditions in the overlying water column.

It is unlikely that a single explanation accounts for the occurrence of $\mathrm{Me}, i$-Bu maleimide (and other Chlorobiaceae biomarkers) at all the investigated sites. Certainly, the allochthonous biomarker hypothesis seems to be an unsatisfactory explanation for the occurrence of $\mathrm{Me}, i$ - $\mathrm{Bu}$ maleimide in sediments deposited on topographic highs and where nearby sites are 
characterized by low organic carbon contents (e.g. DSDP Sites 551 and $763, \mathrm{C} / \mathrm{T}$ boundary $\mathrm{OAE}$ ); in these areas, an intensified oxygen-minimum zone seems to be the most logical explanation. However, an intensified oxygen-minimum zone alone seems inadequate to explain the very high abundances of Chlorobiaceae biomarkers and high TOC contents in deep-ocean sediments.

These results must be interpreted in the context of their specific geological settings, but they do confirm and expand on previous observations that a sulphidic water column was an important characteristic during all three major OAEs of the Jurassic and Cretaceous periods and reinforce previous work (e.g. Jenkyns 1999; Jones \& Jenkyns 2001) suggesting similarities in their causal mechanisms. The results also implicate the role of anoxia as an important control on the occurrence of organic-rich units in Mesozoic sediments (e.g. de Graciansky et al. 1984). Photic-zone euxinic conditions, whether associated with a fully stratified water column or an oxygen-minimum zone, would have facilitated the export of organic matter from the surface ocean and enhanced the preservation of organic matter; this would have complemented associated productivity increases and fostered the sequestration of organic matter in marine sediments.

\section{Conclusions}

It is becoming increasingly apparent that photic-zone euxinic conditions were a characteristic of many ancient marine systems in which organic carbon-rich sediments were deposited. Biomarkers for Chlorobiaceae have been recovered from the Black Sea (Sinninghe Damsté et al. 1993), Plio-Pleistocene Mediterranean sapropels (Passier et al. 1999), and numerous sediments spanning the Phanerozoic (Summons \& Powell 1986; Koopmans et al. 1996, and references therein; Joachimski et al. 2001). This work expands these observations by further illustrating the association of photic-zone euxinic conditions with OAEs and reveals the utility of maleimide and porphyrin distributions in palaeoceanographic investigations. $\mathrm{Me}, i$-Bu maleimide, which, based on structural grounds and its carbon-isotope composition (in $\mathrm{C} / \mathrm{T}$ sediments), derives from $\mathrm{Bchl} d$ or $e$ and is an indicator for photic-zone euxinia, occurs in sediments deposited during the early Toarcian, early Aptian and Cenomanian-Turonian boundary oceanic anoxic events. Although the causes of photic-zone euxinia probably varied among the sample sites and time periods studied, the presence of hydrogen sulphide at shallow-marine levels appears to reflect a stratified water column or an intense oxygen-minimum zone modulated by productivity variations.

The authors gratefully acknowledge the donors of the Petroleum Research Fund (PRF AC-2 042402) for a grant to J.R.M., the NERC for a grant to J.R.M. and H.C.J., and the Nuffield Foundation for a grant to R.D.P. The Ocean Drilling Program provided samples from the Atlantic and Indian Oceans. We would also like to thank J. Carter for analytical support, and M. Sephton and T. Bralower for very useful suggestions that improved the final version of this paper.

\section{References}

Arthur, M.A. \& Primoli Silva, I. 1982. Development of widespread organic carbon-rich strata in the Mediterranean Tethys. In: Schlanger, S.O. \& CitA, M.B. (eds) Nature and Origin of Cretaceous Carbon-Rich Facies. Academic Press, London, 7-54.

Arthur, M.A., Dean, W.E. \& Pratt, L.M. 1988. Geochemical and climatic effects of increased marine organic carbon burial at the Cenomanian/Turonian boundary. Nature, 335, 714-717.

Arthur, M.A., Jenkyns, H.C., Brumsack, H.J. \& Schlanger, S.O. 1990. Stratigraphy, geochemistry and paleoceanography of organic carbon-rich
Cretaceous sequences. In: Ginsburg, R.N. \& Beaudoin, B. (eds) Cretaceous Resources, Events and Rhythms. NATO ASI Series C, 304, 75-119.

BARRon, E.J. 1983. A warm, equable Cretaceous - the nature of the problem. Earth-Science Reviews, 19, 305-338.

Baudin, F., Herbin, J.P. \& Vandenbroucke, M. 1990. Mapping and geochemical characterisation of the Toarcian organic matter in the Mediterranean Tethys and Middle East. In: Durand, B. \& Behar, F. (eds) Advances in Organic Geochemistry, 16, 677-687.

Beerling, D.J., Lomas, M.R. \& Gröcke, D.R. 2002. On the nature of methane gas-hydrate dissociation during the Toarcian and Aptian Oceanic Anoxic Events. American Journal of Science, 302, 28-49.

Bellanca, A., Erba, E., Neri, R., Premoli Silva, I., Sprovieri, M., Tremolada, F. \& Verga, D. 2002. Palaeoceanographic significance of the Tethyan 'Livello Selli' (Early Aptian) from the Hybla Formation, northwestern Sicily: biostratigraphy and high-resolution chemostratigraphic records. Palaeogeography, Palaeoclimatology, Palaeoecology, 185, 175-196.

Bidigare, R.R., Fluegge, A. \& Freeman, K.H. et al. 1997. Consistent fractionation of ${ }^{13} \mathrm{C}$ in nature and in the laboratory: growth-rate effects in some haptophyte algae. Global Biogeochemical Cycles, 11, 279-292.

Bralower, T.J., Arthur, M.A., Leckie, R.M., Sliter, W.V., Allard, D.J. \& SCHLANgER, S.O. 1994. Timing and palaeoceanography of oceanic dysoxia/ anoxia in the late Barremian to early Aptian (early Cretaceous). Palaios, 9, $335-369$.

Brass, G.W., Southam, J.R. \& Peterson, W.H. 1982. Warm saline bottom water in the ancient ocean. Nature, 296, 620-623.

Brown, S.B., Houghton, J.D. \& Hendry, G.A.F. 1990. Chlorophyll breakdown, chlorophyll metabolism. In: ScheER, H. (ed.) Chlorophylls. CRC Press, Boca Raton, FL.

Brumsack, H.J. \& Thurow, J. 1986. The geochemical facies of black shales from the Cenomanian/Turonian Boundary Event (CTBE). In: Degens, E.T. (ed.) Biogeochemistry of Black Shales. Mitteilungen der Geologisch-Palaöntologisches Institut der Universität Hamburg, 60, 247-265.

Chicarelli, M.I. 1985. The Porphyrins of Serpiano Oil Shale: Structures and Significance. University of Bristol, Bristol.

Clarke, L.J. \& Jenkyns, H.C. 1999. New oxygen-isotope evidence for long-term Cretaceous climatic change in the Southern Hemisphere. Geology, 27, 699-702.

Coccioni, R., Erba, E. \& Premoli Silva, I. 1992. Barremian-Aptian calcarous plankton biostratigraphy from Gorgo Cerbara section (Marche, central Italy) and implications for plankton evolution. Cretaceous Research, 13, 517-537.

Cresta, S., Monechi, S. \& PARISI, G. 1989. Mesozoic-Cenozoic stratigraphy in the Umbria-Marche area. Memorie descrittive della Carta geologica d'Italia, 39, 185.

de Graciansky, P.C., Deroo, G., Herbin, J.P., Montadert, L., Muller, C., SchaAf, A. \& Sigal, J. 1984. Ocean-wide stagnation episode in the Late Cretaceous. Nature, 308, 346-349.

de Graciansky, P.C., Deroo, G, Herbin, J.P., Jaquin, T., Magni, F., Montadert, L. \& Muller, C. 1986a. Oceanwide stagnation episodes in the late Cretaceous. Geologische Rundschau, 75, 17-41.

de Graciansky, P.C., Wylie Poag, C. \& Hailwood, E.A. et al. 1986 b. Evidence for changes in Mesozoic and Cenozoic oceanic circulation on the south-western continental margin of Ireland: DSDP/IPOD Leg 80. In: Summerhayes, C.P. \& Shackleton, N.J. (eds) North Atlantic Palaeoceanography. Geological Society, London, Special Publications, 21, 17-34.

Demaison, G.J. \& Moore, G.T. 1980. Anoxic environments and oil source-bed genesis. AAPG Bulletin, 64, 1179-1209.

Dugdale, R.C., Goering, J.J., Barber, R.T., Smith, R.L. \& Packard, T.T. 1977. Denitrification and hydrogen sulphide in the Peru upwelling region during 1976. Deep-Sea Research, 24, 601-608.

Eckardt, C.B., Keely, B.J., Waring, J.R., Chicarelli, M.I. \& Maxwell, J.R. 1991. Preservation of chlorophyll-derived pigments in sedimentary organic matter. Philosophical Transactions of the Royal Society of London, Series B, 333, 339-348.

Erbacher, J., Thurow, J. \& Littke, R. 1996. Evolution patterns of radiolaria and organic matter variations: a new approach to identify sea level changes in mid-Cretaceous pelagic environments. Geology, 24, 499-502.

FARrimond, P. 1987. Toarcian and Cenomanian/Turonian oceanic anoxic events. PhD Thesis, University of Bristol.

Farrimond, P., Eglinton, G. \& Brassell, S.C. 1986. Geolipids of black shales and claystones in Cretaceous and Jurassic sediment sequences from the North American Basin. In: Summerhayes, C.P. \& Shackleton, N.J. (eds) North Atlantic Palaeoceanography. Geological Society, London, Special Publications, 21, 347-360.

Farrimond, P., Eglinton, G., Brassell, S.C. \& Jenkyns, H.C. 1989. Toarcian anoxic event in Europe: an organic geochemical study. Marine and Petroleum Geology, 6, 136-147.

Farrimond, P., Eglinton, G., Brassell, S.C. \& Jenkyns, H.C. 1990. The Cenomanian/Turonian anoxic event in Europe: an organic geochemical study. 
Marine and Petroleum Geology, 7, 75-89.

Freeman, K.H. \& HAYES, J.M. 1992. Fractionation of carbon isotopes by phytoplankton and estimates of ancient $\mathrm{CO}_{2}$ levels. Global Biogeochemistry Cycles, 6, 185-198.

GöRÜR, N. 1991. Aptian-Albian palaeogeography of Neo-Tethyan domain. Palaeogeography, Palaeoclimatology, Palaeoecology, 87, 267-288.

Gradstein, F.M., Kaminski, M.A. \& Agterberg, F.P. 1999. Biostratigraphy and paleoceanography of the Cretaceous seaway between Norway and Greenland. Earth-Science Reviews, 46, 27-98.

Grice, K., Gibbison, R., Atkinson, J.E., Schwark, L., Eckardt, C.B. \& MaXwell, J.R. 1996. 1H-pyrrole-2,5-diones (maleimides) as indicators of anoxygenic photosynthesis in ancient water columns. Geochimica et Cosmochimica Acta, 60, 3913-3924.

Grice, K., Schaeffer, P., Schwark, L. \& Maxwell, J.R. 1997. Changes in palaeoenvironmental conditions during deposition of the Permian Kupferschiefer (Lower Rhine Basin, N.W. Germany) from variations in isotopic compositions of biomarker components. Organic Geochemistry, 26, 677-690.

HaQ, B.U., Hardenbol, J. \& VAIL, P.R. 1987. Chronology of fluctuating sea levels since the Triassic. Science, 235, 1156-1167.

HaQ, B.U., von RAD, U. \& O'ConNell, S. (EDS) 1990. Proceedings of the Ocean Drilling Program, Initial Reports, 122. Ocean Drilling Program, College Station, TX.

HaQ, B.U., Boyd, R.L., Exon, N.F. \& von RAD, U. 1992. Evolution of the central Exmouth Plateau: a post-drilling perspective. In: Dearmont, L.H. \& Mazzullo, E.K. (eds) Proceedings of the Ocean Drilling Program, Scientific Results, 122. Ocean Drilling Program, College Station, TX, 801-816.

Hasegawa, T. 1997. Cenomanian-Turonian carbon isotope events recorded in terrestrial organic matter from northern Japan. Palaeogeography, Palaeoclimatogy, Palaeoecology, 130, 251-273.

Hayes, J.M., Freeman, K.H., Popp, B.N. \& Hoham, C. 1990. Compound-specific isotopic analyses: a novel tool for the reconstruction of ancient biogeochemical processes. In: Durand, B. \& Behar, F. (eds) Advances in Organic Geochemistry 1989, Organic Geochemistry, 1115-1128.

Herbin, J.P., Montadert, L., Muller, C., Gomez, R., Thurow, J. \& WiedmanN, J. 1986. Organic-rich sediments at the Cenomanian-Turonian boundary in oceanic and coastal basins in the North Atlantic and Tethys. In: Summerhayes, C.P. \& Shackleton, N.J. (eds) North Atlantic Palaeoceanography. Geological Society, London, Special Publications, 21, 389-422.

Hesselbo, S.P., Gröcke, D.R., Jenkyns, H.C., Bjerrum, C.J., Farrimond, P., Bell, H.S.M. \& Green, O.R. 2000. Massive dissociation of gas hydrate during a Jurassic oceanic anoxic event. Nature, 406, 392-395.

Hodgson, G.W., Strosher, M. \& Casagrande, D.J. 1971. Geochemistry of porphyrins: analytical oxidation to maleimides. In: VON GAERTNER, H.R. \& Wehner, H. (eds) Advances in Organic Geochemistry. Pergamon Press, Oxford, 151-161.

Hollander, D.J., Besserau, G., Belin, S. \& Huc, A.Y. 1991. Organic matter in the early Toarcian shales, Paris Basin, France: a response to environmental changes. Revue de l'Institut Français du Pétrole, 46, 543-562.

IмноFF, J.F. 1995. Taxonomy and physiology of phototrophic purple bacteria and green sulfur bacteria. In: Blankenship, R.E., Madigan, M.T. \& Bauer, C.E. (eds) Anoxygenic Photosynthetic Bacteria. Kluwer Academic, Dordrecht, $1-15$.

IvanenKov, V.N. \& Rozanov, A.G. 1961. Hydrogen sulphide contamination of the intermediate waters of the Arabian Sea and the Bay of Bengal. Okeanologia, 1, 443-449.

JENKYNS, H.C. 1980. Cretaceous anoxic events: from continents to oceans. Journal of the Geological Society, London, 137, 171-188.

JenKyNS, H.C. 1985. The early Toarcian and Cenomanian-Turonian anoxic events in Europe: comparisons and contrasts. Geologische Rundschau, 74, 505-518.

JenKYns, H.C. 1988. The Early Toarcian (Jurassic) anoxic event: stratigraphic, sedimentary, and geochemical evidence. American Journal of Science, 288, $101-151$.

JENKYNS, H.C. 1999. Mesozoic anoxic events and palaeoclimate. Zentrablatt für Geologie und Paläontologie, 1997, 943-949.

JENKYNS, H.C. 2003. Evidence for rapid climate change in the MesozoicPalaeogene greenhouse world. Philosophical Transactions of the Royal Society, Series A, 361, 1885-1916.

Jenkyns, H.C. \& Clayton, C.J. 1986. Black shales and carbon isotopes in pelagic sediments from the Tethyan Lower Jurassic. Sedimentology, 33, 87-106.

Jenkyns, H.C. \& Clayton, C.J. 1997. Lower Jurassic epicontinental carbonates and mudstones from England and Wales: chemostratigraphic signals and the early Toarcian anoxic event. Sedimentology, 44, 687-706.

Jenkyns, H.C., Sarti, M., MasetTi, D. \& Howarth, M. 1985. Ammonites and stratigraphy of Lower Jurassic black shales and pelagic limestones from the Belluno Trough, Southern Alps, Italy. Eclogae Geologicae Helvetiae, 78, 299-311.

Jenkyns, H.C., Gale, A.S. \& CoRfield, R.M. 1994. Carbon-isotope and oxygenisotope stratigraphy of the English chalk and Italian Scaglia and its palaeoclimatic significance. Geological Magazine, 131, 1-34.

Jenkyns, H.C., GröcKe, D.R. \& Hesselbo, S.P. 2001. Nitrogen isotope evidence for water mass denitrification during the early Toarcian (Jurassic) oceanic anoxic event. Paleoceanography, 16, 593-603.

Jenkyns, H.C., Jones, C.E., Gröcke, D.R., Hesselbo, S.P. \& Parkinson, D.N. 2002. Chemostratigraphy of the Jurassic System: applications, limitations and implications for palaeoceanography. Journal of the Geological Society, London, 159, 351-378.

Joachimski, M.M., Ostertag-Henning, C. \& Pancost, R.D. et AL. 2001. Water column anoxia, enhanced productivity, and concomitant changes in $\delta^{13} \mathrm{C}$ and $\delta^{34} \mathrm{~S}$ across the Frasnian-Famennian boundary (Kowala-Holy Cross Mountains/Poland). Chemical Geology, 175, 109-131.

Jones, C.E. \& JenKyns, H.C. 2001. Seawater strontium isotopes, oceanic anoxic events, and seafloor hydrothermal activity in the Jurassic and Cretaceous. American Journal of Science, 301, 112-149.

Keely, B.J. \& MaXwell, J.R. 1993. The Mulhouse basin: evidence from porphyrin distributions for water column anoxia during deposition of marls. Organic Geochemistry, 20, 1217-1225.

Koopmans, M.P., Schouten, S., Kohnen, M.E.L. \& Sinninghe Damsté, J.S. 1996. Restricted utility of aryl isoprenoids as indicators as indicators for photic-zone anoxia. Geochimica et Cosmochimica Acta, 60, 487-4876.

Kuhnt, W., Thurow, J., Wiedmann, J. \& Herbin, J.P. 1986. Oceanic anoxic conditions around the Cenomanian/Turonian boundary and the response of the biota. In: Degens, E.T. (ed.) Biogeochemistry of Black Shales. Mitteilungen der Geologisch-Palaöntologisches Institut der Universität Hamburg, 60, 205-246.

Kuhnt, W., Nederbragt, A. \& Leine, L. 1997. Cyclicity of CenomanianTuronian organic-carbon-rich sediments in the Tarfaya Atlantic Coastal Basin (Morocco). Cretaceous Research, 18, 587-601.

KuYPERS, M. M. M. 2001. Mechanisms and biogeochemical implications of the mid-Cretaceous global organic carbon burial events. $\mathrm{PhD}$ thesis, University of Utrecht.

KuYPers, M.M.M., Pancost, R.D. \& Sinninghe DamstÉ, J.S. 1999. A large and abrupt fall in atmospheric $\mathrm{CO}_{2}$ concentrations in the Cretaceous. Nature, 399 , $342-345$.

Kuypers, M.M.M., Pancost, R.D., Nijenhuis, I.A. \& Sinninghe Damsté, J.S. 2002. Enhanced productivity led to increased organic carbon burial in the euxinic North Atlantic basin during the late Cenomanian oceanic anoxic event. Paleoceanography, 17(4), 3-1-3-13.

LitTle, C.T.S. \& Benton, M.J. 1995. Early Jurassic mass extinction-a global long term event. Geology, 23, 495-498.

Menegatti, A.P., Weissert, H., Brown, R.S., Tyson, R.V., Farrimond, P., Strasser, A. \& CARON, M. 1998. High-resolution $\delta^{13} \mathrm{C}$ stratigraphy through the early Aptian 'Livello Selli' of the Alpine Tethys. Paleoceanography, 13, $530-545$.

Monaco, P., Nocchi, M., Ortega-Huertas, M., Palomo, I., Martinez, F. \& Chiavini, G. 1994. Depositional trends in the Valdorbia Section (Central Italy) during the Early Jurassic, as revealed by micropaleontology, sedimentology and geochemistry. Eclogae Geologicae Helvetiae, 87, 157-223.

PÁlfy, J. \& Smith, P.L. 2000. Synchrony between early Jurassic extinction, oceanic anoxic event, and the Karoo-Ferrar flood basalt volcanism. Geology, 28, 747-750.

Pancost, R.D., Crawford, N. \& Maxwell, J.R. 2002. Molecular evidence for basin-scale photic zone euxinia in the Permian Zechstein Sea. Chemical Geology, 188, 217-227.

Passier, H.F., Bosch, H.J. \& Nijenhuis, I.A. eT AL. 1999. Sulphidic Mediterranean surface waters during Pliocene sapropel formation. Nature, 397, $146-149$.

Pedersen, T.F. \& Calvert, S.E. 1990. Anoxia vs. productivity: what controls the formation of organic-carbon-rich sediments and sedimentary rocks. $A A P G$ Bulletin, 74, 454-466.

Pettinelli, R., Nocchi, M. \& Parisi, G. 1995. Late Pliensbachian-Toarcian biostratigraphy and environmental interpretations in the Ionian Basin (Lefkas Island, western Greece) as compared to the Umbria-Marchean Basin (Central Italy). Bollettino del Servizio Geologico d'Italia, 114, 97-158.

Pratt, L.M. \& King, J.D. 1986. Variable marine productivity and high eolian input recorded by rhythmic black shales in mid-Cretaceous pelagic deposits from Central Italy. Paleoceanography, 1, 507-522.

Quirke, J.M.E., Shaw, G.J., Soper, P.D. \& Maxwell, J.R. 1980. Petroporphyrins II. The presence of porphyrins with extended alkyl substituents. Tetrahedron Letters, 36, 3261-3267.

Repeta, D.J., Simpson, D.J., Jorgensen, B.B. \& Jannasch, H.W. 1989. Evidence for anoxygenic photosynthesis from the distribution of bacteriochlorophylls in the Black Sea. Nature, 342, 69-72.

Rosell-Melé, A., Carter, J.F. \& Maxwell, J.R. 1996. High performance liquidchromatography mass-spectrometry of porphyrins by using an atmosphericpressure interface. Journal of the American Society of Mass Spectrometry, 7, 965-971. 
Rullkötter, J. \& Mukhopadhyay, P.K. 1986. Comparison of Mesozoic carbonaceous claystones in the western and eastern North Atlantic. In: Summerhayes, C.P. \& Shackleton, N.J. (eds) North Atlantic Palaeoceanography. Geological Society, London, Special Publications, 21, 377-388.

Rullkötter, J., Littke, R., Radke, M., Disko, U., Horsfield, B. \& Thurow, J. 1992. Petrography and geochemistry of organic matter in Triassic and Cretaceous deep-sea sediments from the Wombat and Exmouth Plateaus and nearby abyssal plains off northwest Australia. In: Dearmont, L.H. \& Mazzullo, E.K. (eds) Proceedings of the Ocean Drilling Program, Scientific Results, 122. Ocean Drilling Program, College Station, TX, 317-329.

Ryan, W.B.F. \& CitA, M.B. 1977. Ignorance concerning episodes of ocean-wide stagnation. Marine Geology, 23, 197-215.

SCHLANGER, S.O. \& JenKyns, H.C. 1976. Cretaceous oceanic anoxic events: causes and consequences. Geologie en Mijnbouw, 55, 179-184.

Schlanger, S.O., Arthur, M.A., Jenkyns, H.C. \& Scholle, P.A. 1987. The Cenomanian-Turonian oceanic anoxic event, I. Stratigraphy and distribution of organic rich beds and the marine $\delta^{13} \mathrm{C}$ excursion. In: BRooks, J. \& FleET, A.J. (eds) Marine Petroleum Source Rocks. Geological Society, London, Special Publications, 26, 371-399.

Scholle, P.A. \& Arthur, M.A. 1980. Carbon isotope fluctuations in Cretaceous pelagic limestones: potential stratigraphic and petroleum exploration tool. AAPG Bulletin, 64, 67-87.

Schouten, S., van KaAm-Peters, H., Rijpstra, W.I.C., Schoell, M. \& SinNinghe DAmSTÉ, J.S. 2000. Effects of an oceanic anoxic event on the stable carbon isotopic composition of Early Toarcian carbon. American Journal of Science, 300, 1-22.

Scotese, C.R., 2001. Paleogeographic Map Archive. Paleomap Project.

Sinninghe DAmsté, J.S. \& Köster, J. 1998. A euxinic southern North Atlantic Ocean during the Cenomanian/Turonian oceanic anoxic event. Earth and Planetary Science Letters, 158, 165-173.

Sinninghe Damsté, J.S., Wakeham, S.G., Kohnen, M., Hayes, J.M. \& De LEEUW, J.W. 1993. A 6,000-year sedimentary molecular record of chemocline excursions in the Black Sea. Nature, 362, 827-829.

Sinton, C.W. \& Duncan, R.A. 1997. Potential links between ocean plateau volcanism and global ocean anoxia at the Cenomanian-Turonian boundary. Economic Geology, 92, 836-842.

Sirevag, R., Buchanan, B.B., Berry, J.A. \& Troughton, J.H. 1977. Mechan- isms of $\mathrm{CO}_{2}$ fixations in bacterial photosynthesis studied by the carbon isotope fractionation technique. Archives of Microbiology, 112, 35-38.

SLiter, W.V. 1989. Aptian anoxia in the Pacific Basin. Geology, 17, 909-912.

Summerhayes, C.P. 1987. Organic-rich Cretaceous sediments from the North Atlantic. In: Brooks, J. \& Fleet, A.J. (eds) Marine Petroleum Source Rocks. Geological Society, London, Special Publications, 26, 30-316.

Summons, R.E. \& Powell, T.G. 1986. Chlorobiaceae in Palaeozoic seas revealed by biological markers, isotopes and geology. Nature, 319, 763-765.

Tissot, B., Demaison, G., Masson, P., Delteil, J.R. \& Combaz, A. 1980. Paleoenvironment and petroleum potential of middle Cretaceous black shales in Atlantic basins. AAPG Bulletin, 64, 2051-2063.

Tsikos, H., Jenkyns, H.C. \& Walsworth-Bell, B. ET AL. 2004. Carbon-isotope stratigraphy recorded by the Cenomanian/Turonian Oceanic Anoxic Event: correlation and implications based on three key-localities. Journal of the Geological Society, London, 161, in press.

TURNER, A.D. 1998. Recognition of photic zone anoxia from LC-MS studies of porphyrin distributions in ancient sediments. $\mathrm{PhD}$ thesis, University of Bristol.

van Gemerden, H. \& Mas, J. 1995. Ecology of phototrophic sulfur bacteria. In: Blankenship, R.E., Madigan, M.T. \& Bauer, C.E. (eds) Anoxygenic Photosynthetic Bacteria. Kluwer Academic, Dordrecht, 49-85.

Verne-Mismer, J., Ocampo, R., Callot, H.J. \& Albrecht, P. 1986. Identification of a novel $\mathrm{C}_{33}$ DPEP petroporphyrin from Boscan crude oil: evidence for geochemical reduction of carboxylic acids. Tetrahedron Letters, 37, 52575260 .

Waples, D.W. \& Cunningham, R. 1985. Leg 80 shipboard organic geochemistry. In: Bailey, M.G. (ed.) Proceedings of the Deep Sea Drilling Program, Initial Reports, 80. Ocean Drilling Program, College Station, TX, 949-968.

WARING, J.R. 1991. Sedimentary porphyrins: their significance in depositional environment assessment. PhD Thesis, University of Bristol.

WEISSERT, H. 1989. Carbon isotope stratigraphy, a monitor of palaeoenvironmental change: a case study from the early Cretaceous. Surveys in Geophysics, 10, $1-61$.

Weissert, H., Lini, A., Föllmi, K.B. \& Kuhn, O. 1998. Correlation of early Cretaceous carbon isotope stratigraphy and platform drowning events: a possible link? Palaeogeography, Palaeoclimatology, Palaeoecology, 137, 189-203. 